\title{
COMPLEX VERBS IN NUPE AND YORUBA*
}

\author{
Isaac S. George Madugu \\ University of Ibadan \\ Ibadan, Nigeria
}

\begin{abstract}
This paper examines the structural behaviour of various types of complex verbs in Nupe and Yoruba in relation to causative constructions. When such verbs occur in simplex non-agentive causative sentences as well as in agentive non-causative sentences, they freely permit sentence embedding, resulting in biclausal causative structures. But in the case of non-agentive causatives, it is only Yoruba which allows the verbs to be irregularly embedded into causative matrix sentences in such a way that the biclausal causative structure constitutes input to Causative Clause Union, which compresses it into a uniclausal agentive causative sentence. Functionally, Yoruba uniclausal and biclausal agentive causatives are interchangeable in many cases. On the other hand, only uniclausal agentive causatives are attested in Nupe, as Causative Clause Union has disappeared from its grammar. It is concluded that causative constructions in these languages demonstrate clearly that the CCU rule is motivated by a diachronic process of moving from a pragmatic mode of expression to a syntacticized one, and where a particular target has been hit, the rule ceases to function.
\end{abstract}

\section{0 . Introduction}

Grammatical descriptions of many languages of West Africa have shown that complex verbs comprising two or more syllables exist alongside monosyllabic verbs, which constitute the majority. A few examples include Gwari [Hyman and

*A preliminary version of this paper was presented at the 12 th Conference on African Linguistics, Stanford University, April, 1981, and later at a Seminar of the Department of Linguistics and Nigerian Languages, University of Ibadan. I am grateful to the participants at those gatherings for their useful comments and suggestions. I wish to thank Adekunle Adeniran in particular for assisting me with the Yoruba data. 
Magaji 1970], Idoma [Abraham 1967], Nupe [Banfield and Macintyre 1915, Smith 1969, Madugu 1981], and Yoruba [Ward 1952, Bamgboṣe 1964, Awobuluyi 1978]. A description of the typical morphological composition of such verbs is provided by Ward:

Verb stems may consist of one or more syllables: monosyllabic verbs are very common and there are a number of disyllabic verbs: verbs consisting of more than two syllables are less frequent, and of these, as well as of two-syllable verbs, many are compounds either of two or more verbs or of verbs and nouns ( $p .76)$.

In the present study verbs of the type verb + noun in Nupe and Yoruba are singled out for discussion, 1 the purpose of this is not so much to give a formalistic account of syntactic structures containing them, but to provide evidence to support the notion that diachrony is an important explanatory parameter in language. In particular, following Givón [1979], it will be shown that certain synchronic rules involving these verbs in causative constructions are functionally motivated by diachronic processes of moving from one mode of expression to another and that at the completion of the processes, when a new mode has been rigidly established, the rules are dropped from the grammar.

The study is arranged as follows: section one provides the necessary background information, showing the nature of the morphological make-up of complex verbs and the fact that they have idiomatic meanings. Section two sketches the behavioural patterns of the verbs in causative constructions, where attention is focussed on certain processes of syntacticization. Section three is concerned with the nature of the emerging syntactic mode in which nouns functioning as Indirect objects rather than Direct Objects, being Goal (target) Objects, most of them human, invariably occur immediately after the verb. Its widespread Incidence is also highlighted. It is concluded that the structure can be accounted for in terms of the familiar generalization known as Top-

${ }^{1}$ Nupe and Yoruba, both Kwa languages by Greenberg's [1963] classification and members of the Western South Central N1ger-Congo by Bennett and Sterk's [1977] reclassification, are geographically contiguous, though not closely related genetically. In this study the illustrative materials are given in the orthographical conventions of the languages. Lexical tones are marked as follows: ['] High, ['] Low, and Mid is left without any marking. 
icality Hierarchy. Section four summarizes the discussion.

1. Components of the Complex Verb

A few introductory remarks on the morphological composition of the complex verb will be useful for subsequent discussion. We consider, then, the following examples:
(1) Nupe:
a. mi è dínyé
I Prog. hurry
b. eyé è
dín mi
'I am hurrying'
'I am hurrying'
(2) Yoruba: a. mo ń kánjú
'I am hurrying'
b. ojún kán mi
'I am hurrying'

In the examples of (1) and (2), the verb 'to hurry' in both languages comprises a verbal constituent (VC) followed by a complementing nominal constituent (CNC): Nupe dín(e)yé and Yoruba kán(o) jú. Whereas the two constituents are syntactically contiguous in the (a) sentences of (1) and (2), they are separated in their (b) counterparts. In terms of meaning, there seems to be no appreciable difference between the (a) and (b) versions. ${ }^{2}$

Sometimes the meaning of a verbal component can be specified in isolation, as is the case in (1) and (2) above, where the CNC means 'eye': Nupe eyé and Yoruba ojú. In both languages, however, the VC does not have any independent meaning that we know of. The combination VC + CNC then functions as a semantic unit whose meaning cannot be deduced from the semantic amalgamation of its constituents. As a matter of fact, the meaning of a complex verb is independent of whether the meaning of one constituent, of both constituents, or of none of the constituents can be specified in isolation. The four possibilities are 11lustrated as follows:

${ }^{2}$ Not all complex verbs split in this fashion, but those that do provide a way of recognizing their morphological composiiton. Nupe has an additional means of identifying them. This is by a systematic process of nominalizing $\mathrm{V}+\mathrm{N}$ verbs as distinct from $\mathrm{V}+\mathrm{V}$ ones. Thus dínyé 'to hurry' $\rightarrow$ (e)yédín, (i.e. $\mathrm{V}+\mathrm{N} \rightarrow \mathrm{N}+\mathrm{V}$, and yakpe 'to believe $\rightarrow$ yiyakpe (by partial duplication of the first $V$ ). 
(3)

a.

$$
\text { vc } \overbrace{\text { CNC }}^{\text {complex verb }}
$$

$\begin{array}{llll}\text { Nupe } & \text { dín } & \text { (e)yé } & \text { 'to hurry' } \\ \text { Yoruba } & \text { kán } & \text { (o) jú } & \text { 'to hurry' }\end{array}$

b.

\begin{tabular}{|c|c|c|}
\hline $\begin{array}{l}\text { Nupe } \\
\text { Yoruba }\end{array}$ & $\begin{array}{l}\text { gbín } \\
\text { fẹ }\end{array}$ & $\begin{array}{l}\text { (e)ká } \\
\text { (v) ràn }\end{array}$ \\
\hline
\end{tabular}

c.

$\begin{array}{llll}\text { Nupe } & \text { fé } & \text { (è)dùn } & \text { 'to sit' } \\ \text { Yoruba } & \text { jó } & \text { (V)kòó } & \text { 'to sit' }\end{array}$

d.

$\begin{array}{llll} & + & + & \\ \text { Nupe } & \tan & \text { (e)gwa } & \text { 'to plead' } \\ \text { Yoruba } & \text { yí } & \text { (ọ)wọ́ } & \text { 'to be out of hand' }\end{array}$

( + signifies having meaning in isolation and - signifies its opposite; $(\mathrm{V})=$ Unknown Vowe1)

The first position ( $3 \mathrm{a}$ ) means that the $\mathrm{CNC}$, but not the $\mathrm{VC}$, has meaning in isolation. This has already been noted in the examples of (1) and (2) above. Secondly, in (3b) the VC, but not the CNC, has reference. In Nupe gbin means 'to perish', but -ká has no independent reference. Similarly, the Yoruba VC fọ by itself may mean 'to love/want/marry', but an isolated meaning of the CNC -ràn is not known. Thirdly, (3c) stipulates that neither constituent of the complex verb has meaning in isolation. The verb 'to sit' (Nupe féèdùn and Yoruba jókòó) illustrates this. Fourthly, (4d) shows the possibility that both of the verbal constituents have identifiable references. Thus in Nupe we have $\tan +$ egwa 'rub hand', the semantic amalgam of which is different from the idiomatic meaning 'to plead'. And in Yoruba we have $y \hat{~}+$ o owọ 'to turn the hand', the semantic combination of which is different from the meaning 'to be out of hand'. ${ }^{3}$

${ }^{3}$ Bamgbose [1964], in fact, points out that in general, even if a Yoruba monosyllabic verb collocates with a noun and we find the same form fused into one (verb) elsewhere, the meaning of the two forms will be different, e.g. kó erọn: kẹrọn (by contraction) 'collect meat' but kẹrọn means 'to be done for ${ }^{i}$. Awobuluyi [1978:55] also remarks that the idiomatic meanings of such 
From the above observation, it is clear that complex verbs have idiomatic meanings. It is on the basis of this fact that a complex verb is regarded as a single lexical unit in this discussion, as opposed to a monosyllabic verb followed by its object, for example, 'to bruise one's arm' (Nupe bó + (e)kpá , Yoruba bó + apá ). To recognize a VC and its CNC as separate entities will amount to claiming that each entity is an independent lexical entry, and this will lead to positing many lexical items in the lexicon which will at times lack dictionary meanings.

It should be observed that the CNC in (1) and (2) is a body part ('eye'). This is not an isolated case, for there are instances of other parts of the body involved, as the following partial lists show (where independent meanings of the verbal components are not available for morpheme-by-morpheme glossing, simply VC or CNC will be used):

\begin{tabular}{|c|c|c|c|}
\hline Nupe & a. gbómi & $\begin{array}{l}\text { gbó emi } \\
\text { bark mouth }\end{array}$ & 'to argue' \\
\hline & b. patí & $\begin{array}{l}\text { pa etí } \\
\text { tie head }\end{array}$ & 'to be apprehensive' \\
\hline & c. sungwa & $\begin{array}{l}\text { sun egwa } \\
\text { VC hand }\end{array}$ & 'to hold' \\
\hline Yoruba & a. bínú & $\begin{array}{l}\text { bí inú } \\
\text { VC stomach }\end{array}$ & 'to be angry' \\
\hline & b. jệwọ́ & $\begin{array}{l}\text { jẹ ơwó } \\
\text { reply hand }\end{array}$ & 'to confess' \\
\hline & c. retí & $\begin{array}{l}\text { re eti } \\
\text { vC ear }\end{array}$ & 'to expect' \\
\hline & d. jáyà & $\begin{array}{l}\text { já ayà } \\
\text { snap hear/chest }\end{array}$ & 'to be afraid' \\
\hline & e. yọnu & $\begin{array}{l}\text { yo ęnu } \\
\text { pu11 out mouth }\end{array}$ & 'to give trouble' \\
\hline
\end{tabular}

But it is not the case that all CNC's are body parts. Sometimes they are probably cognate or indefinite objects:

(6) Nupe a. kpógun kpó egun 'to shout'
VC CNC 


$\begin{array}{lll}\text { b. zèwùn zè ewùn } & \begin{array}{l}\text { 'to be angry' } \\ \text { turn angry }\end{array} & \text { 'to quarrel' } \\ \text { c. sunwùn sun ewùn } & \begin{array}{l}\text { VC anger } \\ \text { d. sundàn sun edàn } \\ \text { VC fear }\end{array} & \text { 'to be afraid' }\end{array}$

\begin{tabular}{|c|c|c|c|}
\hline \multirow[t]{5}{*}{ Yoruba } & a. pàșẹ & $\begin{array}{ll}\text { pa } & \text { àșẹ } \\
\text { utter } & \text { order }\end{array}$ & 'to order' \\
\hline & b. bẹ̀rù & $\begin{array}{l}\text { bà èrrù } \\
\text { impinge on fear }\end{array}$ & 'to be afraid' \\
\hline & c. jiyọ̀n & $\begin{array}{l}\text { jà iyọ̀n } \\
\text { fight dispute }\end{array}$ & 'to argue' \\
\hline & d. dàmú & $\begin{array}{ll}\text { dà àmu } \\
\text { vC }\end{array}$ & 'to worry' \\
\hline & e. bèèrè & $\begin{array}{ll}\text { bi èrè } \\
\text { ask } & \text { CVC }\end{array}$ & 'to ask' \\
\hline
\end{tabular}

The existence of complex verbs amidst predominantly monosyllabic verbs in these languages poses a number of interesting questions. One of them is whether such verbs constitute a distinct subcategory of verbs, reflecting in any significant way common syntactic and semantic features, apart from their typical CV-CNC structure. Further, one may inquire as to what factors control the structural behaviour of the CNC. And a very intriguing question could involve the evolution of such verbs. The rest of this discussion will focus attention primarily on the first two of the questions.

\section{Transitivity and Causativity}

Complex verbs in Nupe and Yoruba do not constitute a homogeneous subcategory of verbs, nor are they in opposition to monosyllabic verbs in terms of subgroupings. In other words, there are various subgroupings of complex verbs denoting different notions such as action, stativity, etc., just as there are monosyllabic verbs functioning in the same manner. For the purpose of this discussion, their syntactic and semantic properties will be examined from the perspective of Transitivity as proposed in Hopper and Thompson [1980] (HT).

According to them Transitivity is not merely a binary system of grouping clauses into Transitives and Intransitives, but a system comprising a number of parameters, "each of which suggests a scale according to which clauses can be ranked" (p. 252). The parameters are as follows: 
$\mathrm{HIGH}$

(8) A. PARTICIPANTS

B. KINESIS

C. ASPECT

D. PUNCTUALITY

E. VOLITIONALITY

F. AFFIRMATION

G. MODE

H. AGENCY

I. AFFECTEDNESS OF 0

J. INDIVIDUATION OF 0
2 or more participants, $A$ and 0

action

telic

punctua 1

volitional

affirmative

realis

A high in potency

0 totally affected

0 highly individuated
LOW

1 participant

non-action

atelic

non-punctual

non-volitional

negative

irrealis

A low in potency

0 not affected

non-individuated ${ }^{4}$

HT explain that when the parameters are "taken together, they allow clauses to be characterized as MORE or LESS Transitive: the more features a clause has on the 'high' column... the more transitive it is-the closer it is to CARDINAL Transitivity" (p. 253).

An ideal Transitive clause then will have all the features on the HIGH column, while a least Transitive one will have all the features on the LOW column. The majority of clauses in any given language will fall between the two extremes. The question then arises as to how to determine the degree of Transitivity in given clauses. In order to achieve that purpose in this study, sentences will be characterized in terms of Causativity. Admittedly, causativity is an extremely complex topic, and its ramifications will not be discussed in this study. Instead, it will be shown that Nupe and Yoruba use syntactic rather than morphological mechanisms for causative expressions.

It is generally agreed that Causativity involves at least two participants (NP's) in a sentence, in which one participant, often designated the Agent, does something, intentionally or otherwise, and the other participant (the Ob-

${ }^{4}$ In their teminology, $A$ and $O$ refer to Agent and object respectively. They explain that Actions are transferable. Aspect-wise they may be telic (completed) or atelic; they may also be punctual, i.e. "with no obvious transitional phase between inception and completing", or non-punctual. 
ject) is physically or emotionally affected by the activity of the Agent. It must, however, be emphasized that at times causative constructions are possible without Agents, in the narrow sense of the term. A causative verb then will express the activity of the instigating participant and its effect on the recipient participant. Syntactically, it will have at least one more participant than a corresponding non-causative verb.

It is important to note here that the salient features of Causativity, for example, Agency and Volitionality, are part of the defining parameters of Transitivity in (8) above. It is therefore expected that a clause which ranks high in Transitivity will also be highly causative, without implying that Transitivity and Causativity are understood to mean the same thing. We now examine various structures which will be characterized as follows:

(9) a. Non-agentive non-causative

b. Agentive non-causative

c. Non-agentive causative

d. Agentive causative

Accordingly, how various sub-groups of complex verbs in Nupe and Yoruba function in (9a-d) will be examined.

As can be seen from the Parameters in (8), A, E, H, I, J relate closely to nouns; $B, C$, and $D$ are closely associated with verbs; and $F$ and $G$ are more of a global nature. The first two sets are relevant for our consideration of complex verbs, but since the discussion will deal only with affirmative sentences, assumed to be possible in a real world, no further reference will be made to $F$ and $G$.

2.1. Non-agentive non-causative constructions. The examples of (10) and (11) below illustrate this kind of construction:
(10) Nupe
Bàbá gbóká
'Baba is strong'
Baba be-strong
(11) Yoruba
Bàbá sanra
'Baba is fat'
Baba be-fat

The sentences in (10) and (11) are non-agentive non-causative, since they contain neither Agentive nouns nor causative verbs. They also lack specifiable 
objects, despite the inclusion of the CNC's. In terms of Transitivity features, they are non-action, and therefore non-transferrable. They score extremely low, perhaps the lowest possible, on the Transitivity scale. In the familiar terminology they are stative constructions. More examples of non-Agentive non-Causative verbs include Nupe lekpan 'to be thick', gopè 'to be wide', and wúnkpá 'to be tall'; Yoruba lera 'to be strong in body' and mọra 'to be light in complexion'. 5

Although Nupe and Yoruba do not have derivational causatives, the same effect can be produced by embedding non-causative sentences into matrix sentences containing causative verbs such as take, get, and make, resulting in biclausal causative sentences of the type (12) and (13) directly below:
(12) Nupe
cinginni
lá Bàbá gbóká pounded-yam made Baba strong
(13) Yoruba iyán mú Bàbá sanra
pounded-yam made Baba fat
'pounded-yam made Baba strong'
'pounded-yam made Baba fat'

Even though (12) and (13) are causative constructions, we should observe that the CAUSE element 'pounded-yam' is not a volitional Agent. It, however, has Potency.

As far as I know, there are no instances of Non-agentive non-causative complex verbs occurring in a configuration of the type [CNC-VC-(NP)].

2.2. Agentive non-causative constructions. These are sentences of the type:
(14) Nupe
mi bici
'I ran'
I ran
(15) Yoruba mo sáré
'I ran'
I ran

The major characteristic features of an Agentive non-causative are as follows: first, the NP subject is, in general, Agentive endowed with Volitionality and Potency. Second, the verb expresses action. Third, the action is atelic and non-punctual, and fourth, there is no object. The construction type therefore

${ }^{5}$ There are, of course, monosyllabic stative verbs in both languages, e.g. Nupe sà 'to be beautiful', ge 'to be good' and Yoruba ga 'to be tall', fè 'to be broad'. 
scores high in terms of the first two sets of features mentioned above but low in the last two.

Like non-agentive non-causative sentences, agentive non-causative structures can be embedded into causative matrix clauses:
(16) Nupe Makun jin mi bici
Makun made me run

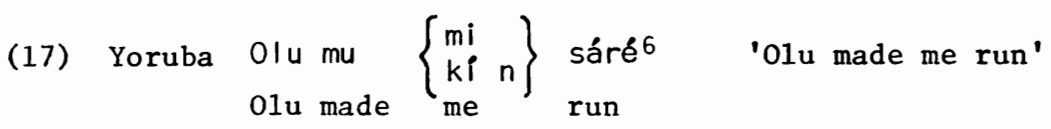
'Makun made me run'

Since agentive non-causative express actions, naturally they often have adverbial phrases indicating the location, direction, etc. of the activities expressed by the verbs.
(18) Nupe
a. u dazàn lo dzukó he/she walked went market
b. u kóni yà $y^{7}$ he/she sang gave us
'he/she walked to the market'
'he/she sang for us'
(19) Yoruba a. o kọrin fún wa he/she sang gave us
b. o ránṣẹ sí wa he/she sent to us
'he/she sent (a message) to us'

'he/she sang for us'

One other feature of this type of construction worth noting is the fact that in certain circumstances, specifically, in some kind of focus construction and in relativization the verbal components can be separated from each other, the CNC being fronted:
(20) Nupe
a. eci gá mi bi o
CNC it-be I ran Foc.
'what I did was running'
b. [eci na ni bi na] máfi etsu CNC ECM I ran ECM pleased chief $(\mathrm{ECM}=$ Embedded Clause Marker)
'the race that I ran pleased the chief'

${ }^{6}$ In many cases the Yoruba form $k i$ optionally introduces embedded clauses; when it occurs before $\mathrm{mi}$ ' $m \mathrm{e}^{\prime}$, the variant $\mathrm{n}$ is often used.

${ }^{7}$ In both languages certain verbs, e.g. go, give, are used 1ike prepositions 
(21) Yoruba a. eré ni mo sá

CNC Foc. I ran

b. [ere tí mo sá] dùnmọ́ ọba CNC that I ran pleased chief 'what I did was running'

'the race that I ran pleased the chief'

The (a) sentences of (20) and (21) are focus constructions, while those of (b) are nominalizations. ${ }^{8}$

Finally, verbs such as ask and answer, which fall within this subgroup, sometimes appear as discontinuous elements:

\begin{tabular}{|c|c|c|c|c|c|}
\hline \multirow[t]{3}{*}{ (22) } & Nupe & a. & $\begin{array}{l}\text { Makun gbingàn } \\
\text { Makun asked }\end{array}$ & & 'Makun asked' \\
\hline & & b. & $\begin{array}{l}\text { Makun gbingàn etsu } \\
\text { Makun asked chief }\end{array}$ & & 'Makun asked about the chief' \\
\hline & & c. & $\begin{array}{l}\text { Makun gbin etsu gan } \\
\text { Makun asked chief CNC }\end{array}$ & & $\begin{array}{l}\text { 'Makun asked the chief (a } \\
\text { question)' }\end{array}$ \\
\hline \multirow[t]{3}{*}{ (23) } & Yoruba & a. & $\begin{array}{l}\text { Olú béèrè } \\
\text { Olu asked }\end{array}$ & & '01u asked' \\
\hline & & b. & $\begin{array}{l}\text { Olú béèrè ọba } \\
\text { olu asked chief }\end{array}$ & & '01u asked about the chief' \\
\hline & & c. & $\begin{array}{l}\text { Oll bi oba } 1 \\
\text { olu asked chief part. }\end{array}$ & $\begin{array}{l}\text { éèrè } 9 \\
\text { CNC }\end{array}$ & $\begin{array}{l}\text { '01u asked the chief (a } \\
\text { question)' }\end{array}$ \\
\hline
\end{tabular}

The (a) sentences of (22) and (23) express the fact that someone asked a question, but the locutionary target is not included. The (b) versions state that someone asked about the chief, but in the (c) constructions the chief is the locutionary target to whom the question was directed. It is a definite and hu-

\footnotetext{
${ }^{8}$ In Nupe the form na...na is used to set off certain types of embedded clauses, e.g.

(i) mi si efin na nú na

'I bought a razor that is sharp'

(ii) u ge na mi a si efin na (sentential complement)
'it is necessary that I should buy a razor'

(iii) efin gá ù yì o na mi si na (focus)

'it is razor that I bought'
}

${ }^{9}$ The Yoruba particle ni (underlyingly /Iî/) has a variant Ií, which may appear as $\mathrm{l}$, depending on the phonological environment. 
man noun, functioning as an Indirect object. Meanwhile the CNC is demoted to the syntactic position after the Io. In the case of Yoruba, the particle if is inserted before the CNC. This is a syntactic operation similar to the wellknown Dative Movement. We should notice, however, that in both languages the structures of (b) and (c) have different semantic interpretations. The demotion phenomenon will be further discussed in section 3 .

2.3. Non-agentive causative constructions. Though few in number, non-agentive causative verbs, the type of which is exemplified by sentences (1) and (2) (repeated below for convenience), are by far the most interesting subset of complex verbs.
(1) Nupe
a. mi è dínyé
I Prog. hurry
'I am hurrying'
b. eyé è diń mi
'I am hurrying'
(2) Yoruba a. mo ń kánjú
'I am hurrying'
b. ojú ń kán mi
'I am hurrying'

For ease of reference, structures like (1a) and (2a) will be labelled A and those of (1b) and (2b) as B. More examples of such verbs are given in (24), showing their typology: 10

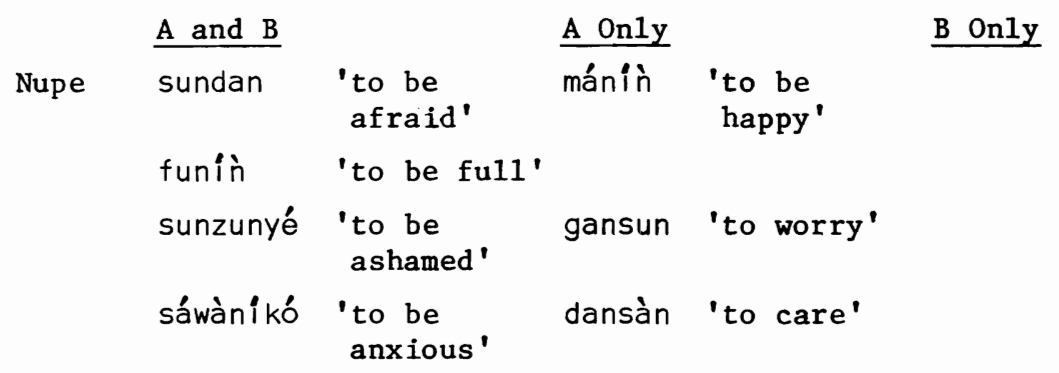

${ }^{10} \mathrm{Although}$ the Yoruba complex verb dájú 'to be sure' is non-agentive causative, it cannot be labelled as A or B since its subject is invariably a non-referent ó 'it' as in ó dájú pé... 'it is sure that...' and in Agentive Causative Constructions (see 2.4) it appears in a split form as in ó dá mi lójú pé... 'I am sure that...' 


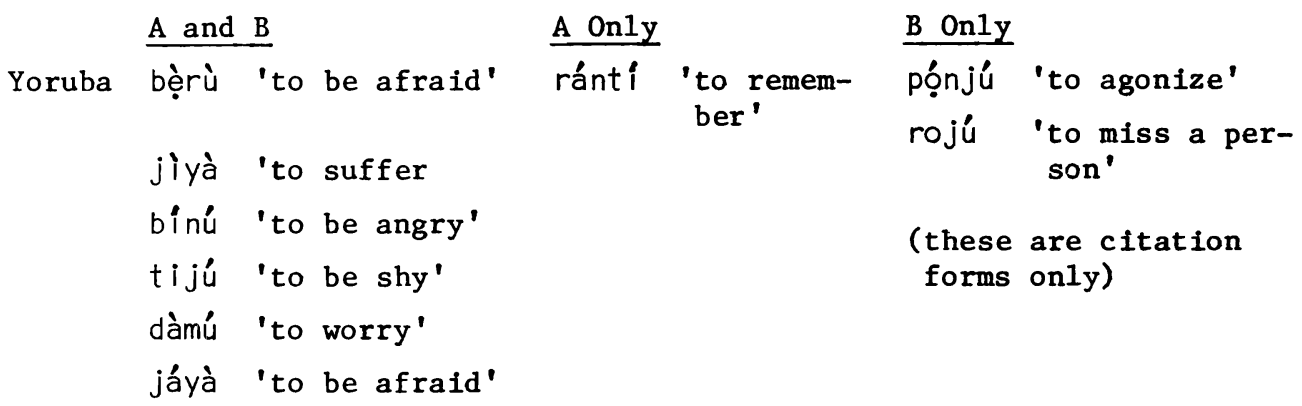

It is important to observe that structures containing these verbs relate strictly to animate nouns, most often human, and they express conditions which have arisen from the effect of activities of causative Agents or situations, though missing from the structures. Concerning their Transitivity features, they are non-action. There are no Agents, though personal pronouns occur in the subject position of the A structures. In fact, human nouns in these examples are Experiencer Nouns (EN).

One obvious peculiarity of the non-agentive causative complex verbs is the fact that some of them allow both structures $A$ and $B$, which means that the syntactic positions of the EN and the CNC are interchangeable. It is thus the case that if the former is in the subject position the latter functions as the object and vice versa, causing no difference in semantic interpretation. What is responsible for the alternation, and which of the two structures is basic synchronically? That is, given $A$ and $B$, which one has been least (or has not been) disrupted by syntactic transformation?

Discussing causative constructions in English, Noriko McCawley [1976:197] observes that a non-agentive causative "involves one and the same human experiencer both in the subject and in the object of CAUSE. That is, someone's learning through his senses or perceiving something inevitably evokes in him a certain emotional reaction expressed by a variety of emotive adjectives such as happy, sad, surprised, amazed, shocked, etc." One example is It made Dale sad that sue might marry Bill.

If this is correct, a human experiencer both as the subject and object of CAUSE is capable of having structures like A and $B$ respectively. And precisely, this is what obtains in the case of the verbs which permit both $A$ and $B$ struc- 
tures. In both construction $A$ and $B$ the human Experiencer is being affected (typically by his stomach, eye, heart, etc.). In the B type the body part is made the subject while the Experiencer is object ([CNC VC EN]). The EN is also the object in the structure of non-agentive causative sentences containing monosyllabic verbs in which nouns comparable to CNC's (but not incorporated into the verbs) function as subjects. Consider then the following:
(25) Nupe

$$
\begin{aligned}
& \text { a. mi ̀̀ gun madan } \\
& \text { I Prog. VC hunger } \\
& \text { b. madan è } \text { gun mi } \\
& \text { hunger Prog. VC me }
\end{aligned}
$$$$
\text { 'I am hungry' (=A) }
$$$$
\text { 'I am hungry' (=B) }
$$

$\begin{array}{llll}\text { (26) Yoruba a. mo h pa ebi } & \text { 'I am hungry' (=A) } \\ & \text { I Prog. feel hunger } \\ & \text { b. ebi h h pa mi } \\ \text { hunger Prog. feel me } & \text { 'I am hungry' (=B) }\end{array}$

The examples of (25) and (26) illustrate non-agentive causative constructions comparable to those of (1) and (2). The difference between the two sets resides in the fact that the noun 'hunger' is not incorporated into the verb and that it alone functions as the subject, as the EN is excluded from that position. Since affected individuals are more topic-worthy than body-parts or other non-human nouns, speakers may prefer to make an affected human the subject, thus giving rise to the A configuration [EN VC-CNC] as an alternative, a process which enhances the fusion of VC-CNC into a semantic unit.

It is possible then that the B structure is the earlier form historically, and the Yoruba complex verb occurring only in this structure could be seen as "Islands" unaffected by the innovation that brought about A. Conversely, those verbs whose occurrence is restricted to A have completely stopped being used in their earlier syntactic form.

It is appealing to consider $B$ as the basic form synchronically, but this is ruled out by the fact that complex verbs in both languages, as was pointed out in section 1, have been lexicalized as single units. Apart from that CNC's generally lack the universal subject properties such as independent existence, autonomous reference, and high referentiality like pronominalization [Keenan 1976]. 
2.4. Agentive causative constructions. This type of construction is arrived at through the embedding of structures considered in 2.3 in higher causative clauses, following which other processes may produce rather elaborate simple sentences. In principle then, agentive constructions are expressed in two ways, and this is the case in Yoruba, where uniclausal and biclausal causatives exist alongside each other. Nupe, on the other hand, has gone a step beyond Yoruba in the sense that only uniclausal causatives are used. Here are a few examples:
(27) Nupe

$$
\begin{aligned}
& \text { a. Makun lá mi dínyé } \\
& \text { Makun caused me hurry } \\
& \text { b. *Makun lá eyé dín mi } \\
& \text { c. Makun dín mi yé }
\end{aligned}
$$$$
\text { Makun hurried me CNC }
$$
'Makun made me hurry'

(A)
(28) Yoruba a. Olú mú $\left\{\begin{array}{l}k i \\ m i\end{array}\right\}$ bínú 'Olu made me angry' o1u caused me angry

$$
\begin{array}{ll}
\text { b. Olu mú (ki) inú bí mi } & \text { 'Olu made me angry' } \\
\text { c. Olu bí mi ní nú } & \text { 'Olu made me angry' }
\end{array}
$$

The Nupe non-sentences of $(27 a, b)$ are biclausal structures, which simply show that agentive sentences are not expressed in that form, irrespective of whether the embedded clause is structurally A (27a) or B (27b). Instead, the uniclausal of the type (27c) is the mode for such expressions. But the Yoruba sentences of (28) show three ways of expressing Agentive causative, two of which are biclausal, i.e. $(28 \mathrm{a}, \mathrm{b})$, where the embedded clauses have the structures $A$ and $B$ respectively, while (28c) is a uniclausal and, in fact, the counterpart of Nupe (27c). All three structures have the same semantic interpretation. ${ }^{11}$ Although all of the sentences of (28) can be used interchangeably, (28c) has a non-causative additional meaning, which is something like 'the mere sight of olu annoys me'.

The syntactic rule involved in the derivation of Yoruba (28) is the familiar Causative Clause Union, attested in many languages, for example, French [Herschensohn 1981] and Georgian [Cole et al 1980]. This is the rule which maps bi-

${ }^{11}$ The relationship between Yoruba biclausal and uniclausal Causatives with complex verbs is irregular, both structurally and semantically (see (32) and (33) below). 
clausal consturctions as schematized in (29a) onto (29b) below.

(29) a. $\mathrm{NP}_{1}$ CAUSE $\mathrm{S}_{2}^{[\mathrm{NP}} \mathrm{VP}_{\mathrm{S}}$

b. $\mathrm{S}_{1}^{[\mathrm{NP}}$ cause-verb $\left.\mathrm{NP}_{2} \mathrm{NP}_{3}\right]_{\mathrm{S}}$

Details aside, rule (29a) will convert the following Yoruba (30) to (31).

(30)

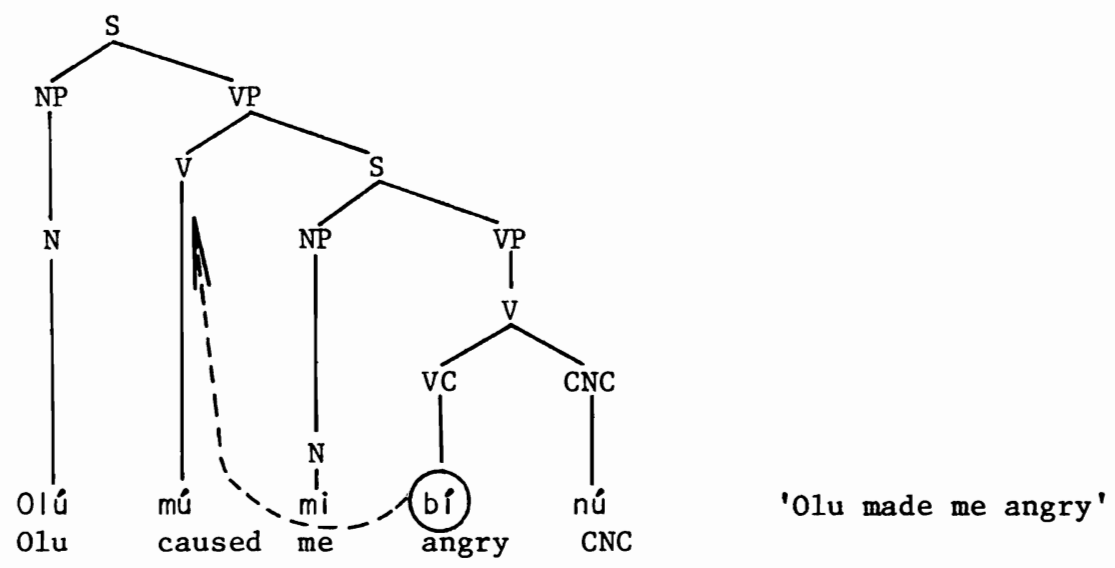

(31)

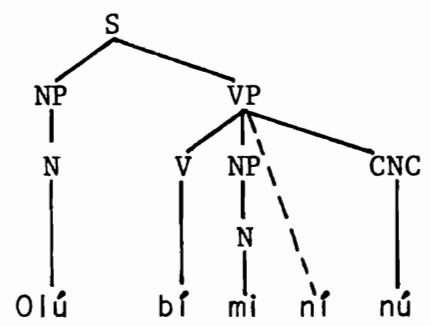

'Olu made me angry'

The important syntactic processes include Predicate Raising, which attaches the embedded verb (VC) to the cause verb (leading to the fusion of the two), and the eventual disappearance of the cause verb of the matrix clause with subsequent Pruning. Finally, the particle $n i$ is inserted before the CNC. The emerging structure (31) is a compressed form of (30), though an elaborate simplex sentence in itself, as it contains two nouns (the CNC inclusive) and a particle in the predicate phrase.

The productivity of the Causative Clause Union rule in Yoruba is quite limited, and the trend is clearly that the mode represented by (31) is emerging as 
a terse, syntacticized form. This is easily supported by the fact that sometimes there are structures like (31) without corresponding biclausal sentences of the type (30). Thus example (32b) below is unlikely to be derived from the ungrammatical (32a):
(32) a. *ộọ náà mú mi yanu
matter the caused me surprised
'the matter surprised me'
b. ọ̀rọ náà yà mí l ệnu
'the matter surprised me'

In (32) the syntacticized form (32b) has become rather rigid, and there is no oscillation between biclausal and uniclausal Causatives in such cases.

Another piece of support for the position that Causative Clause Union has a limited productivity in Yoruba comes from the fact that occasionally certain . uniclausal Causatives superficially appear to be derivable from corresponding biclausal Causatives, but in reality this is not the case. Consider, then, the following:
Yoruba
a.
Ayọ mú mi ránti ilé
Ayọ caused me remember home
b. Ayọ rán mi l éti ilé
Ayo reminded me part. CNC home
'Ayo made me remember home'
'Ayo reminded me of home'

Clearly, the meaning of (33b) is sufficiently different from that of (33a) as to cast doubt on their derivational relationship.

We have seen that the operation of Causative Clause Union is weak in Yoruba and non-existent in Nupe. The situation is therefore that in Yoruba there is considerable amount of oscillation between the use of biclausal and uniclausal Causatives. But the oscillation is non-existent in Nupe, because the uniclausal construction has been firmly established as a syntactic mode.

This is significant, as it goes beyond a mere formulation of syntactic rules present in one language but absent in another, and illustrates a major diachronic process as proposed in Givón [1979:208], namely that "pragmatic discourse structures develop-over time-into tight, grammaticalized syntactic structures."12 Further, Givón isolates two "extreme poles of communicative

${ }^{12}$ Diachronic processes, of course, occur in other aspects of language, in- 
mode: the pragmatic mode and the syntactic mode", under which loose conjunction and tight subordination fall respectively (p. 223). Since our main concern is with a movement from tight subordination to complex uniclausal structures, we would like to propose that in fact tight subordination is an intermediary stage between the poles.

\section{(34) Pragmatic Mode Intermediary Mode Syntactic Mode Loose conjunction Tight subordination Compressed uniclause}

In this regard, the biclausal causative construction, which constitutes input to Causative Clause Union, is a relatively loose structure, in the sense that it comprises two clauses put together by embedding rules, where the matrix clause explicitly expresses what the causing Agent or situation is and the embedded clause states the effect. It could then be said that it is cast in a near-pragmatic mode, because it is somewhat iconic by nature. Given time, it would develop into a tighter syntactic mode, and this is precisely what we have. In Nupe the process has been completed in this particular instance, and thus causative expressions involving complex verbs-the output of Causative Clause Union-are cast in uniclausal constructions containing two nominals in the predicate phrase. In Yoruba, however, the process is an on-going phenomenon.

We should note in passing that it seems also that in Yoruba the movement in the direction of Morphology has already been set in motion. Not only do we have a process of rigid syntacticization in Causativity, but the rigidity is being extended to the lexicon, such that some Causative verbs include in their citation forms the particle ní as in:
(35)
Yoruba

$$
\begin{array}{ll}
\text { a. rànlộoó } & \text { (< ràn } x \text { I } \tilde{i} \text { ọọ́ ) } \\
\text { b. yàlẹnu } & \text { (< yà } x \text { Ii ẹu ) }
\end{array}
$$
'to help'
'to be surprised'

cluding morphology and morphophonemics. Givón schematically represents the "cyclic waves" as

$$
\begin{gathered}
\text { Discourse } \rightarrow \text { Syntax } \rightarrow \text { Morphology } \rightarrow \\
\text { Morphophonemic } \rightarrow \text { Zero (p. 209). }
\end{gathered}
$$




\section{The Syntax of the Uniclausal Causative}

In this section we discuss the syntax of uniclausal causatives, particular$1 y$ in terms of their word order, Transitivity and in terms of their relation to other syntactic processes.

3.1. Uniclausal Causatives and Transitivity. The structure of the uniclausal causative sentence discussed in (2.4) above, given in (36a), as opposed to the non-occurring (36b), shows what the "real" Transitive object is:

(36) a. Agent - VC - EN - (Particle) - CNC

b. *Agent - VC - CNC - EN

In concrete examples we have:
(37) Nupe
a. Bàbá è dín mi yé Baba Prog. hurry me CNC
b. *Bàbá è dínyé mi
(38) Yoruba a. Bàbá ń kán mi l ójú 'Baba is making me hurry' Baba Prog. hurry me Par. CNC
b. *Bàbá ń kánjú mi

In (37a) and (38a) the word order of the nouns in the predicate phrase is ENCNC, which means that the CNC has been separated from its VC and is now the rightmost constituent in the sentence. In a sense this is a kind of "demotion". The EN on the other hand is "promoted" to the position immediately after the verb, i.e. the VC.

The syntactic position of the EN is indicative of the fact that it has more Transitivity features than the CNC. This structural position has to be the case, since the only strategy for signalling Transitivity in both languages is syntax: the closer an object is to the verb the more Transitive it is.

The above observation that the EN has more Transitivity features than the CNC is in agreement with HT's argument that "Indirect objects in fact should be Transitive objects" ( $\mathrm{p}$. 259). The basis of their argument is that Indirect $\mathrm{Ob}-$ jects tend to be definite and human, quite often reflecting a high degree of Transitivity. Evidence in support of this is found in many Bantu languages, and Sesotho (from Morolong and Hyman [1977:203]) is cited as an example: "When 
two nouns follow the verb one of which is human, the other of which is non-human, the human noun MUST, independent of its semantic case, follow the verb."

We may then characterize the syntactic arrangement of nouns in the predicate phrase of Nupe and Yoruba uniclausal causatives in terms of Transitivity Hierarchy (39) below:

(39) Transitivity Hierarchy: EN > CNC

$$
\text { ( }>\text { means higher than) }
$$

The schema in (39) stipulates that the EN is higher than the CNC on the Transitivity scale and, accordingly, it follows the verb, having displaced the latter. It is worth noting that the idea that the EN is higher on the Transitivity scale than the CNC makes sense only when the situation is considered in the light of Affectedness, which should be interpreted not only in the physical sense but also in emotional terms.

The effect of the conformity of the Causative structure to (39) is the placing of the CNC in a "demoted" position. This means a disruption of the expected word order from VC-CNC-EN to VC-EN-CNC has taken place. As pointed out in Givón [1979:146], when a disruption of this nature has occurred, the problem of recoverability of the case function of the displaced nouns arises. In such instances languages have an option of resorting to the use of certain strategies for recovering the lost cases. Precisely, Yoruba, but not Nupe, uses the particle ní before the CNC to achieve that purpose. In fact the phenomenon of placing human nouns right after the verbs and the concomitant demotion of the CNC is related to wider processes in these languages, which we examine directly below.

3.2. Transitivity Hierarchy in a wider context. In the study of the ni-OBJECT (or Inverted Object) construction in Yoruba, Awobuluyi [1969] and Madugu [1982] have shown that certain kinds of Yoruba constructions, including Dative Objects, Possessives and Causatives, etc. alternate with ní-OBJECT structures. A few examples are as follows:

(40) a. Bàbá fi è̀wù fún ọba DO - I0 Baba took gown gave chief

'Baba gave the gown to the chief' 
b. Bàbá fún ọba ní ẹ̀wù IO - DO

Baba gave chief part. gown

'Baba gave the chief a gown'

(41) a. olè jí è̀ù̀ ọba Do - Poss

thief stole gown chief

'a thief stole the gown of the chief'

b. olè jí ọba ní è̀ù POSS-Do

thief stole chief part. gown

'a thief stole the chief's gown'

(42) a. oúnjẹ náà mú ínú run ọmọ DO - EN

food the caused stomach constipate child

'the food constipated the child'

b. oúnjẹ náà run ọo ni ínú EN - Do

food the constipated child part. stomach

'the food constipated the child'

(43) a. olè $f i$ ọ̀bẹ gún ọba INST. - Do

thief used knife stab chief

'a thief used a knife to stab the chief'

b. olè gún ọba ní ọ̀bẹ DO - INST.

thief stabbed chief part. knife

'a thief stabbed the chief with a knife'

Nupe also has structures which parallel those of (40) through (43), but without any particle:

(44) a. Bàbá lá èwò yà etsu DO - I0

Baba took gown gave chief

'Baba gave the gown to the chief'

b. Bàbá yà etsu èwò $\quad$ I0 - Do

Baba gave chief gown

'Baba gave the chief a gown'

(45) a. yígbèci yí èwò (yán) etsu Do - Poss

thief stole gown (of) chief

'a thief stole the gown of the chief' 

b. yígbèci yí etsu èwò
POSS - DO
thief stole chief gown
'a thief stole the chief's gown'

(46) a. eyangíci lá gbàko tán egi Do - EN

food caused stomach pain child

'the food constipated the child'
b. eyangíci tán egi gbàko EN - DO
food pained child stomach

'the food constipated the child'
(47) a. yígbèci lá èbi tun etsu INST - DO
thief used knife stabbed chief
'a thief used a knife to stab the chief'
b. yígbèci tun etsu èbi DO - INST
thief stabbed chief knife

'a thief stabbed the chief with a knife'

Viewed from the perspective of discourse pragmatics, Madugu [1982] groups nouns, mostly human, functioning in various environments as Indirect object, Experiencer, Possessive, etc. as Goal objects and accounts for the ni-OBJECT constructions in terms of information focus and relative topicality of NP's in the sentence, concluding that the Goal object is more topical than the Direct object (GO > DO); hence the Object Shift rule,

(48) $\mathrm{DO}-\mathrm{GO} \rightarrow \mathrm{GO}-\mathrm{DO}$

obtains in the sentences of the type (40) through (43). The Nupe constructions (44-47) above can be equally accounted for in this manner.

In another study, Madugu [1981], mainly concerned with Transitive Complex Verbs in Nupe like dàgwa 'to push' as in
(49) a. Musa dà mi gwa
Musa pushed me CNC
'Musa pushed me'
b. Musa dà kpàko gwa
'Musa pushed the door'

the CNC is characterized as Fused Instrumental (FI), which undergoes the process of Demotion. Nouns in the predicate phrases in such constructions are therefore 
accounted for in terms of the Topicality Hierarchy (50):

(50) $\mathrm{Su}>\mathrm{DO}>\mathrm{FI}$

The emerging picture is extremely remarkable. First, we should note that the (a) sentences of $(40-47)$, like the Yoruba biclausal causative constructions, are pragmatic structures. In fact, with the exception of the possessive sentences (41a) and (45a), they are serial verbal constructions, which are highly iconic in the sense that the order of verbs in a sentence corresponds to the order of the events they describe, e.g. X took $\mathrm{Y}$ gave $\mathrm{Z}$. But their (b) counterparts, like the uniclausal causatives, are cast in a tight syntactic mode, where the number of the verbs is reduced, and the predicate phrase now contains two nouns. The syntactic processes that effect the Inverted object Constructions must be similar to Causative Clause Union, at least in kind, having the force of compressing two clauses into one. These processes, we must note, are still operative in Nupe, including Agentive Causatives, e.g. (46) above, which do not involve complex verbs.

Second, just as Causative Clause Union is only weakly operative in Yoruba, so must be the rules of Inverted object Constructions in both languages, for there are occasions where compressed structures exist without corresponding loose counterparts:
(51) Nupe u gí mi gbàtà
'he owes me a debt'
he owes me debt
(52) Yoruba ó jẹ mí ní gbèsè
'he owes me a debt' he owes me part. debt

It is obvious, then, that the trend of moving from loose pragmatic structures to tight syntacticized ones is a widespread phenomenon in the two languages.

As a matter of fact, the alternation between the pragmatic and compressed sentences involving take and cause has been attested in Ijọ as well. Givón [1975:95] cites the following examples (taken from williamson [1965]):
(53) a. erí, opúru-mo
he crayfish-the taki tọboú pộr boy $\frac{\text { ta }}{\text { give-Asp }}$
b. erí, opúru-mọ-ni tọbọ́ pị̂ri-mi
he crayfish-the boy give-Asp.
'he gave the crayfish to the boy'
'he gave the crayfish to the boy


(54) a. erí, uru akị-nị u-mịẹ-nì uru bou-mí

he wine take him Cause wine drink Asp.

'he made him drunk with wine' or 'he made him drink wine'

b. erí, uru akị-nị u-bou-mó-mị ${ }^{13}$

he wine take him-drink-Cause-Asp.

'he made him drink wine'

Very likely, then, this kind of oscillation is common among the serializing languages of West Africa.

Third, in all instances of compressed sentences-Inverted object Construction, uniclausal causatives, and Nupe Transitive Clauses involving complex verbs-it is the Goal object that functions as the Transitive Object and any other noun follows. Clearly, the processes are similar. What is needed now is a generalization which will account for them. This can be done in terms of the familiar Topicality Hierarchy.

(55) $\mathrm{Su}>\mathrm{DO}>\mathrm{IO}>\mathrm{OBL}>$ others $^{14}$

To arrive at the $\mathrm{TH}$ (55) Goal objects are optionally promoted to the position of the DO, while the original DO is demoted. Similarly, in Causative constructions as well as some Transitive structures in Nupe, IO's are placed right after the verbs and the CNC's are demoted.

4. Summary and Conclusion

Complex verbs in Nupe and Yoruba have been investigated and found to be heterogeneous. Those which occur in non-agentive non-causative constructions

${ }^{13}$ Givón observes that in (54b) the lexical 'make/cause' is deleted, while the verb bou 'drink' acquires a causative suffix (-mọ); but in some cases 'make' and -mo coexist, as in

(i) erí, árụ-bị mịe bilemọ-mi 'he made the canoe sink' he canoe-the make sink-Asp

(ii) erí, árụ-bị bilemo-mi 'he sank the canoe' he canoe-the sink-Asp

${ }^{14} \mathrm{Cf}$. the generalization expressed by Keenan and Comrie [1977] concerning the accessibility to relative clause formation of NP's, given as:

$\mathrm{SU}>\mathrm{DO}>\mathrm{IO}>\mathrm{OBL}>\mathrm{GEN}>\mathrm{OCOMP}$ 
as well as those which occur in agentive non-causative constructions fully allow sentence embedding, resulting in biclausal causative structures. In the case of non-agentive causatives, however, the picture is different. In Yoruba, occasionally, but not always, these verbs can be optionally embedded into causative matrix sentences, such that they constitute input to Causative Clause Union, which maps them onto uniclausal agentive causative constructions. The result is that the latter are highly syntacticized and alternate with biclausal agentive causative sentences. In Nupe, due to the fact that Causative Union is no longer operative, only uniclausal causative constructions are found.

The importance of Causative Clause Union is highlighted. It clearly demonstrates that, as a syntactic process, it is motivated by diachronic processes, and in the instance of Nupe, where a particular target has been hit, it is dropped from the grammar. We have noted that in Yoruba the trend is in that direction as well.

It has also been shown that the emerging, compact, uniclausal causative constructions, where Experiencer nouns are the real Transitive objects, bear a close relationship to Inverted Object Constructions in both languages, all of which can be accounted for in terms of the generalization known as Topicality Hierarchy •

We would like to stress that in synchronic grammars certain formal rules are functionally motivated in the sense that they are a reflection of diachronic processes in languages, where there are movements from one mode of expression to another. We conclude therefore that syntactic rules in synchronic grammars are better understood with reference to diachronic processes. The study above is an attempt in that direction. 


\section{REFERENCES}

Abraham, R. C. 1967. The Idoma Language. London: University of London Press. Awobuluyi, oladele. 1969. "The particle î in Yoruba." Journal of West African Languages 6:67-77.

Awobuluyi, oladele. 1978. Essentials of Yoruba Grammar. Ibadan: Oxford University Press.

Bamgboșe, Ayọ. 1964. "Verb-nominal collocation in Yoruba: a problem of syntactic analysis." Journal of West African Languages 1:27-32.

Banfield, A. W. and J. L. Macintyre. 1915. A Grammar of the Nupe Language. London: Society for Promoting Christian Knowledge.

Bennett, P. R. and J. P. Sterk. 1977. "South Central Niger-Congo." Studies in African Linguistics 8:241-273.

Cole, P., W. Harbert, G. Hermon and S. N. Sridhar. 1980. "The acquisition of subjecthood." Language 56:719-743.

Givón, Talmy. 1975. "Serial verbs and syntactic change." In Charles N. Li (ed.), Word order and Word order Change, pp. 46-112. University of Texas Press.

Givón, Talmy. 1979. On Understanding Grammar. New York: Academic Press.

Greenberg, J. H. 1963. The Languages of Africa. Bloomington, Indiana University.

Herchensohn, Julia. 1981. "French causatives." Linguistic Analysis 8:217-280.

Hopper, P. J. and S. A. Thompson. 1980. "Transitivity in grammar and discourse." Language 56:251-299.

Hyman, Larry M. and Daniel J. Magaji. Essentials of Gwari Grammar. Occasional Publication No. 27., Institute of African Studies. Ibadan: University of Ibadan Press.

Keenan, Edward L. 1976. "Towards a universal definition of 'subject'." In Charles N. Li (ed.), Subject and Topic, pp. 303-333. New York: Academic Press.

Keenan, Edward L. and Bernard Comrie. 1977. "Noun phrase accessibility and universal grammar." Linguistic Inquiry 8:63-99.

Madugu, I. S. G. 1981. "The Nupe verb and diachrony." Ibadan Journal of Humanistic Studies 1:74-97.

Madugu, I. S. G. 1982. "The ni-OBJECT construction in Yoruba." Journal of African Languages and Linguistics 4:43-58.

McCawley, Noriko A. 1976. "On experiencer causative." In Masayoshi Shibatani (ed.), Syntax and Semantics 6: The Grammar of Causative Constructions, pp. 181-203. New York: Academic Press. 
Morolong, Mali1lo and Larry Hyman. 1977. "Animacy, objects, and clitics in Sesotho." Studies in African Linguistics 8:199-217.

Smith, N. V. 1969. "The Nupe verb." African Language Studies 10:90-160.

Ward, Ida C. 1952. An Introduction to Yoruba. Cambridge: W. Heffer and Sons Ltd. 
